\title{
Does electromagnetic therapy meet an equivalent counterpart within the organism?
}

\author{
Richard HW Funk* \\ Institute of Anatomy, Medical Faculty, TU Dresden, Fetscherstr, 74, 01307 Dresden, Germany
}

\begin{abstract}
This review bundles all available new information about intrinsic electrical phenomena in many types of cells (also non-neural) and tissues and shows that exogenously applied electric fields (as DC - EF, EMF or pulsed electromagnetic fields PEMF) can couple to the endogenous electrical phenomena of the body. These endogenous fields are generated ubiquitously in all tissues via cellular ion pumps and transporters and these ion gradients can be transferred by gap junctions. Such electric phenomena can now be monitored in living cells and tissues by electro-sensitive markers. Observations are now available from early embryonic development on to wound healing and regeneration within the adult organism. Based on these grounds we demonstrate that endogenous electric fields act directly on classical pathways of molecular and cell biology. Adequately applied frequencies and pulsing from outside can couple to these endogenous fields or to the receptors of classical biochemical pathways and manifest in positive "reprogramming" of tissue functions. In sum, this new analytical approach to the bodies' own electrical information processes opens up new avenues for adequate EMF and PEMF therapy.
\end{abstract}

\section{Introduction}

In the last decades many clinical studies were published which show beneficial effects of electric field (EF), electromagnetic field (EMF) or pulsed electromagnetic field (PEMF) therapy. If one looks over the vast amounts of publications, it is hard to find a common scientific base for the frequencies, time sequences of applications and intensities used. And often this therapy is questioned in principle because of a supposed lack of an adequate counterpart for EMF therapy from outside.

So we address in the present review following questions:

1) Do the EMF/PEMF triggers used in therapy meet an equivalent counterpart in the biological tissue? - Means, are similar electric fields generated endogenously or is no counterpart existing?

2) Which studies in literature show interactions of EMF/PEMF with the "classical" cell biology - and which mechanisms of coupling and which effects show in vitro and in vivo animal experiments as well as clinical studies?

\section{Equivalent counterpart in the organism?}

Elaborated studies could show that electrical and ion gradient phenomena are intrinsic to biological systems. These electric field gradients ("bioelectricity") are not only created by small ions but are also driven by larger biomolecules. These charge driven electric fields trigger pathways such as cell signaling, tissue factors, growth hormones, transmitters etc [1-7]. Since about ten years from now, new methods like membrane potential- and ion-sensitive in vivo dyes as well as constructs for imaging and molecular tracing are available, allowing a direct observation of the mentioned processes in cells, tissues and living systems. Thus, also effects of electric fields coming from outside as influencing factors to this endogenous bioelectricity and other targets can be studied adequately.

In living organisms, electromagnetic fields are generated endogenously mostly as direct current fields (DC) or ultra-low frequency (ULF)-EMF [6]. These fields arise from the segregation of charges by molecular pumps, transporters and ion channels situated in the plasma membrane [8]. Thus, they are not spikes of action potentials like in nerve (required field $10-20 \mathrm{~V} / \mathrm{cm}$ ) cells but smoothly changing - like ULF - EMF.

It is important to look first at the resting potential of the cell. Means indeed each type of cell in the body has to maintain it specific level of resting potential at the cell membrane. Differentiated cells possess a high membrane potential with the highest for neurons $(-75 \mathrm{mV})$, glia $(-90 \mathrm{mV})$ and muscle cells $(-50 \mathrm{mV})$. In embryogenesis resting potential values range from $-8.5 \mathrm{mV}$ in the fertilized egg to $-23 \mathrm{mV}$ in the fourcell till $-25 \mathrm{mV}$ in the 16 -cell frog embryo [5,9]. It is intriguing that, in general, malignant cancer cells $(0-10 \mathrm{mV})$ as well as proliferating cells (CHO, 3T3, etc., -12 to $-25 \mathrm{mV}$ ) have low cell membrane (resting) potentials $[10,11]$.

Recent studies imply that the resting potential is a key regulator of cell cycle as well as of proliferation. Depolarization of cell membrane potential by external changes in ion concentration inhibits G1/S progression of Schwann' cells, astrocytes, fibroblasts and lymphocytes. This suggests that hyperpolarization should be important for initiating S - phase [12-14]. Many proteins are involved in this membrane potential triggered cell cycle control [14]. For G2/M transition, depolarization of the plasma membrane should be mandatory. In total

*Correspondence to: Richard HW Funk, Institute of Anatomy, Medical Faculty, TU Dresden, Fetscherstr, 74, 01307 Dresden, Germany, Tel: +49 351 4586110; Fax: +49 351 4586103; E-mail: Richard.funk@tu-dresden.de

Key words: cell biology, tissues, endogenous electric fields, classical signaling pathways, electromagnetic fields, pulsed electromagnetic fields, therapy

Received: January 03, 2017; Accepted: January 10, 2017; Published: January 18, 2017 
a rhythmic change to hyperpolarization before DNA synthesis to longer depolarization during mitosis can be found as general pattern in tissue embryogenesis and regeneration [15].

For regenerative therapy the fact is important, that in normal human mesenchymal stem cells (hMSCs), cell differentiation is accompanied by a progressive hyperpolarization. Artificial depolarization holds these cells in an undifferentiated (stem - like) state, while artificial hyperpolarization accelerates differentiation [16]. In the next step of transduction from changes in resting membrane potential to intracellular mechanisms it is discussed an increasing Ca++ entry into the cell and a positive feedback loop between $\mathrm{Ca}++$ entry and $\mathrm{Ca}++$ dependent potassium channels [17]. In further signaling cascades till gene regulation, e.g. phosphatase and tensin homolog (PTEN) is involved as well as epigenetic regulators like histone decarboxylase (HDAC).

Cell cycle can also determine cell fate in diseases, means depending on outside conditions, the resting membrane potential level can switch in a flip flop manner into different states - especially if the order between the cells is perturbed during a diseased state. This may happen also between larger groups of cells; because ion transmitting gap junctions exist as well as other ways to convey information. Nowadays even computer modeling studies arise, showing how groups of cells with altered membrane potential level behave compared to normal cells [18].

On the other hand, relatively few papers exist how the resting potential in cells and group of cells is altered in pathogenesis, e.g. during inflammation. It is only known that inflammation causes a lowering of the threshold for action potentials [19]. Regarding inflammationinduced joint pain, Hatch et al., describe that hyperpolarizationactivated cyclic nucleotide-gated (HCN) channels are implicated [20].

In fact, the observation that the level of resting potential can switch from a diseased potential back to normal could be a very good argument for EMF / PEMF therapy [10]. Means, this therapy may trigger the tendency of the resting potential into the direction of a switch back from diseased to normal state. However, before we go to action mechanisms of PEMF therapy and to reactions of cells and tissues, let us first see how endogenous bioelectricity is working normally in healthy and wounded tissue as well as in a regenerating organism.

During early embryonic development, bioelectric fields are actively generated by passive $\mathrm{Na}+$ uptake and by ion transporters (ion pumps). Differences in charge gradients between various regions are forming intraembryonic voltage gradients (about $1-5 \mathrm{~V} / \mathrm{cm}$ ). A depolarization of a neuron by surface electrodes requires a field of $10-20 \mathrm{~V} / \mathrm{cm}$. In contrast to these short - lived action potentials of neurons, small endogenous EF of all other cell types last very long and build up gradients that persist from UL- EMF to minutes and weeks, means [4].

Patterns of cell membrane potentials arise even in fertilized eggs and can be clearly demonstrated by electrosensitive dyes in life cell imaging [3]. Electric field gradients also influence larger charged molecules like growth factors or other charged signaling molecules - demonstrating significant links to classical biochemical signaling pathways (e.g. via serotonin) [21,22]. A network of open gap junctions then distributes signaling further [23]. After spreading the signal via gap junctions it is transmitted further into the classical signaling cascades. Ultimately, these signaling molecules control the expression of genes and also epigenetic mechanisms. Carneiro et al. found that these signaling molecules mentioned control the expression of genes (also epigenetics e.g. by a histone decarboxylase -HDAC- dependent intracellular receptor) [24]. This explains how electric gradient formation in single cells can lead to large-scale morphogenetic gradients.

In embryogenesis, during wound healing and regeneration as well as in vitro, many cell types normally migrate in along an electric field at field strengths of $0.1-10 \mathrm{~V} / \mathrm{cm}$, like neural crest cells, fibroblasts, osteoblasts, keratinocytes, chondrocytes, rat prostate cancer cells and many epithelial cell types [25-31]. Regarding sensing of such fields, our group found that the function of $\mathrm{Na}, \mathrm{K}-\mathrm{ATPase}$ and a $\mathrm{Na}+\mathrm{H}+$ exchanger isoform (NHE3) could act also as directional sensors [2931]. The information is transferred via a mechanism that involves PIP2 as a mediator and the cell membrane potential acts as a regulatory cue. This maintains persistent direction in electrotaxis. Also genes involved in these electrotaxis phenomena have been found during wound healing e.g. phosphatase and tensin homolog (PTEN) enzymes are involved [32].

In wound healing, in general, enhanced DC- EF are present especially in epithelial layers. Here, a transepithelial potential is generated with the cathode at the wound center. It is possible that $\mathrm{EF}$ are the earliest signals that an epithelial cell receives to initiate directional migration into the dermal wound bed $[33,34]$. This signal lasts for many hours and regulates different cell behaviors within 0.5 $\mathrm{mm}$ to $1 \mathrm{~mm}$ from the wound edge. After complete re-epithelialization, the signal fades [4]. Kucerova et al. could also show that EFs after wounding arise initially and later on, other factors (like growth factors etc.) take over [35].

Regarding regeneration, the present models show that $\mathrm{H}+$ pump (V-ATPases)- dependent changes in membrane voltage are an early mechanism inducing e.g. tail (spinal cord, muscle and vasculature) regeneration in Xenopus [36]. After amputation, the regeneration bud depolarizes, but after $24 \mathrm{~h}$ it repolarizes due to V-ATPase activity. The cell-surface V-ATPase is also up regulated at the mRNA and protein levels within $6 \mathrm{~h}$ of amputation - an extremely early step in the regeneration process. More recently, Özkucur et al. could show that ion contents in the axolotl tail blastema change dynamically during regeneration and, in most cases, are still fluctuating at $48 \mathrm{~h}$ post amputationem whereas after 24 hours, downstream pathways (BMP, Notch, Msx, Wnt and Fgfs) are activated [37,38]. After 7 days this regeneration is completed.

Electromagnetic fields (EMF) are also produced endogenously within the organism. One should keep in mind that many rhythms are present in the nervous system, in the musculoskeletal system and within all connective tissue. Frequencies from 5 to $30 \mathrm{~Hz}$ were found during postural muscle activity (quiet standing) and of $10 \mathrm{~Hz}$ during walking [39]. So everything in living systems is in motion and changing magnetic fields are associated with changing EF. Thus, endogenous EMF and PEMF arise from the movement of muscles, tendons, etc. and the actions of the musculoskeletal system itself. Mechanical deformation of dry bone causes piezoelectricity. Furthermore, bending strain couples to the spatial gradients of permanent dipoles in collagen molecules [40,41]. At physiological conditions, mechanical stressgenerated potentials are formed by the streaming potential, which is the electric potential difference between a liquid and a capillary, diaphragm, or porous solid through which it is forced to flow, or the electrokinetic processes, i.e. movement of ions because of fluid motion within tissues [42].

At the dimensions of single cells, enzymatic and metabolic activities of cells are mostly processed rhythmically. Thus, every substrate change and every small metabolic cycle has its own up and 
down often in a sinus wave with a typical frequency [43]. However, the situation within cells and tissues is extremely complex and far from being completely understood. We have more than ten thousands of biochemical reactions happening simultaneously within a single cell [44]. Furthermore, coupling mechanisms of EMF and PEMF into the cascade of cell reactions are revealed only partially. On the other hand, our techniques to trace these coupling phenomena by modern cell biology now are far more sophisticated. So also the mechanistic impact of "electrotherapy" can be monitored more precisely - at least in standardized experimental situations in vitro and partly in vivo. In clinical situations it is more complicated again, however, also here relatively hard data now arise via many double blinded and randomized trials, showing the specific benefit of such therapies - especially for the use of PEMF as therapeutic trigger to enhance healing and regeneration processes.

Thus, recent in vitro studies begin to reveal how such EMF or PEMF stimuli are coupled or linked to the classical signaling pathways in molecular biology and genetics.

If the EMF or especially PEMF is strong enough, then Faraday coupling is the most plausible mechanism. Faraday coupling means magneto-electric induction or triggering surface charges on the cell membrane [45]. Here, charges and ions on the cell membrane can be moved. Furthermore, it is possible that receptors on the cell membrane can be set into motion if the EMF frequency hits the resonance frequency of a swinging molecular antenna within a receptor, transporter or another signaling element within the cell membrane $[46,47]$. It is clear that by this Faraday induction can influence also the resting potential of the cell.

Because the magnetic component of EMF can intrude into the cell, Faraday's induction law is also applicable within the cell, as demonstrated by reorganization of the electrostatically negative charged actin filaments. Cho et al. showed that a 1 or $10 \mathrm{~Hz}$ field changed microfilament structure from an aligned form to globular patches, whereas higher frequencies $(20-120 \mathrm{~Hz})$ had no effect [48]. Possibly, the moment of inertia in the actin fibers could not follow the changing field at higher frequencies, whereas at low frequencies the steady distortion inhibited formation of the typical cable-like structures.

In line with Faraday coupling is electroconformative coupling which means that periodic changes of an electric field can change the conformation of molecules in general and especially of cellular enzymatic systems, especially those within membrane structures $[49,50]$. Here, the EMF or PEMF pulses can be converted into chemical energy by enhancing the turn over speed of metabolically active systems, which can convert also signaling molecules and thus trigger cellular reactions. The sensitivity of this effect can be significantly enhanced by stochastic resonance, which means that a signal that is normally too weak to be detected by a sensor, can be boosted by addition of a "white noise" mixture of frequencies. By this "package" of white noise frequencies the original signal is amplified whereas the rest of the white noise remains in the same amount. So finally the signal overcomes the threshold to be detected by the sensor, which then can resonate with the original, previously undetectable signal [51].

EMF penetration of the cell can happen without massive attenuation. Thus, these fields can interact with cell organelles as well as with the DNA directly. In this context, Lin et al. found besides the heat sensitive region of heat shock protein gene (HSP 70) also an EMF sensitive region (electro responsive element - EMRE) [52,53]. Also the promotor of c-myc possesses such an EMRE [54]. Here we have a direct coupling of EMFs to classical cell biological signaling pathways.

Electrical fields induced by PEMF fields can be transported over larger distances by gap junctions. Thus, electric fields spread over distances up to millimeters in an embryonic or adult organism. Gap junctions are also termed "electrical synapses" in neurosciences [55]. Special proteins build up a certain channel or junction within neighboring cells membranes to form a gap junction. By gap junctions, groups of cells can exchange ions (e.g. $\mathrm{Ca}++, \mathrm{K}+$ ), however, also second messengers like cAMP, cGMP, IP3 or metabolites very rapidly, thereby building up gradients in their membrane potentials. Thus, EF can spread very quickly [55]. Gap junctions connect nearly all cell types, and interestingly connect also cells, which are not residing in close proximity, rather are connected by extended processes that often also possess gap junctions [56].

Finally, the most prevailing species of free radicals within a cell are radical oxygen species (ROS and hydroxyl radicals) and radicals formed by nitric oxide (NO) [57]. The lifetime of a free radical is varying dramatically - less than a nanosecond till $3-5 \mathrm{~s}$ in NO [57]. The radical pair phenomenon (NO, ROS) can thus interfere with endogenous oscillations in cell or metabolic systems. Resonance effects that greatly enhance (in phase), or diminish or extinguish (counter phase) characterize this interplay. Rosenspire et al. have shown in experiments with neutrophils and weak magnetic pulses that it is possible to modulate endogenous metabolic oscillations, which influence the production rate of reactive oxygen species and nitric oxide [58]. They propose an electrically sensitive membrane-embedded receptor complex, such as VSP, which transduces the signal to $1-25 \mathrm{~Hz} \mathrm{Ca} 2+$ pulses. With regard to the release of $\mathrm{NO}$ a strong boost in blood circulation was evidenced $[59,60]$. Here, the activation of the vasodilatative component of $\mathrm{NO}$ may be of significance [61]. Indeed, our group could also show a direct increase in NO produced by endothelial cells in an in vitro study [59].

In many species the ROS triplet phenomenon is used for sensing magnetic field lines - mostly in birds. Triplets are generated by the radical producing impact of blue light within the photoreceptors. Then, the mechanism works as follows: the direction of the magnetic field lines interferes with triplet orientation and by aligning of the free triplet radical along the field lines the photoreceptor cells have get an orientation cue. And, because the photoreceptors are aligned in perfect hemispheres, retinae are ideal antennas. In an experiment with birds and yellow filter glasses upon their eyes, the birds had no blue light radicals anymore, and - consequently no directional information means the birds lost orientation [62].

\section{Interactions of EMF/PEMF with "classical" cell biol- ogy - in vitro and in vivo animal experiments as well as clinical studies}

Based on these new and consolidated cell and molecular biological grounds the "bioelectric" way can be applied to many clinical situations e.g. diabetic peripheral neuropathy.

In situations like diabetic peripheral neuropathy the literature shows that in the PEMF area many clinical observations exist, $[59,63,64]$; whereas the literature is very inconsistent for in vitro studies on neuronal cells as well as for studies with molecular- and cell biological background [65-72]. On the other hand, a profound understanding of the ongoing processes, especially of potential neuroprotective effects - see also such EF effects in patients of retinal degeneration would be very useful e.g. for the large number of diabetic 
patients that have impaired axonal transport of transmitters within existing peripheral nerves as well as deficits in regrowth of impaired and damaged neuronal processes of autonomic nerves and wound healing [73-76].

For these situations DC EF can be applied with electrodes only in restricted areas whereas PEMF has the ability to penetrate deeper into the tissue [66] and to reach larger areas. Here, carrier frequencies in the $\mathrm{kHz}$ range were used to surmount possible higher impedances within the tissue. Other PEMF studies work in the low $\mathrm{Hz}$ range from $2 \mathrm{~Hz}$ on [64].

The cell biological effects described in the above mentioned studies reach from general enhancement of viability to increase of neurotrophic or other growth factors, influence of cytokines as well general cytoprotection. Activation of the vasodilatative nitrogen oxide (NO) may be of significance, too [61]. Indeed, our group could also show a direct increase in NOs produced by endothelial cells in an in vitro study [59]. The aforementioned impact mechanisms combined with increased blood circulation and the signal cascade of NO might be an important strand of the PEMF effect.

Osteogenic differentiation is enhanced in MSCs by PEMF only if the cells are pre-committed [77]. Means in detail, that MSCs derived from adipocytes differentiate faster and more expressed if they are cultured in a medium favoring osteogenic differentiation. Zhai et al. could show that PEMF stimulation with $15.38 \mathrm{~Hz}$ at $20 \mathrm{Gs}(2 \mathrm{mT})$ for $2 \mathrm{~h}$ /day enhanced osteoblastic functions through amelioration of the cytoskeletal organization; increased proliferation-related gene expressions (including Ccnd 1 and Ccne 1) as well as upregulated gene and protein expressions of collagen type lof the Runt-related transcription factor 2 and of Wnt/ $\beta$-catenin signaling (Wnt1, Lrp6, and $\beta$-catenin) at proliferation and differentiation phases [78]. In a rat rotator cuff repair model PEMF therapy improves tendon to bone healing. Joint function was not altered; however, the bone quality was improved [79].

On the other hand neural differentiation was favored after PEMF treatment in human bone marrow MSCs [80]. The expression of neural markers such as NF-L, NeuroD1 and Tau was enhanced. Furthermore, a cell protective effect was found via the PI3K/Akt/Bad signaling pathway. In nerve crush experiments in rats, peripheral nerve regeneration could be enhanced by PEMF as well as by addition of Schwann - like cells derived from human dental pulp stem cells [81]. In guinea pigs, Veronesi et al. could show that PEMF $(75 \mathrm{~Hz})$ ameliorated all symptoms of knee osteoarthritis [82].

Positive PEMF influence is also reported on the anabolic activity of chondrocytes, a chondroprotective effect is observed on joint cartilage and on spontaneous osteoarthritis in animal models [83-91]. At the same time, the catabolic effect of IL $-1 \mathrm{~b}$ is reduced $[91,92]$. Furthermore an increased gene expression in members of the Transforming Growth Factor (TGF - $B$ ) family is effected [93]. The local expression of TGF - $B$ hereby also results in improved bone fracture healing [94], whereby the proliferation, differentiation and synthesis of cartilage matrix proteins are also improved $[85,95]$.

In clinical studies applied PEMF at varying carrier (high) and modulation (low) EMF frequencies [96]. The treated knee of the osteoarthritis patients had less pain, less stiffness and an increased physical function. Two meta - analyses by Negm et al. [97] (7 studies analysed) and Ryang We et al. [98] (14 studies analysed) show very positive effects of PEMF in the management of knee osteoarthritis.
In our own randomized, placebo controlled PEMF study with an electrode-less device we found in osteoarthritis patients significant reduction in stiffness and a significant reduction in disability in daily activities [64]. The device (MagCell) -delivered a sinusoidal magnetic field with varying in a frequency of 4 and $12 \mathrm{~Hz}$ and a magnetic flux density of $105 \mathrm{mT}$ even in $1 \mathrm{~cm}$ tissue depth.

As an overall conclusion of all clinical PEMF studies mentioned above, one can recommend the PEMF as mono - therapy or as additional therapy in combination with pharmaceutical therapy. This recommendation can now be fostered by reputable research in molecular and cell biology.

\section{References}

1. Levin M (2009) Bioelectric mechanisms in regeneration: Unique aspects and future perspectives. Semin Cell DevBiol20: 543-556. [Crossref]

2. Levin M (2011) The wisdom of the body: future techniques and approaches to morphogenetic fields in regenerative medicine, developmental biology and cancer. Regen Med 6: 667-673. [Crossref]

3. Levin M (2014) Molecular bioelectricity: how endogenous voltage potentials contro cell behavior and instruct pattern regulation in vivo. MolBiol Cell 25: 3835-3850. [Crossref]

4. McCaig CD, Rajnicek AM, Song B, Zhao M (2005) Controlling cell behavior electrically: current views and future potential. Physiol Rev 85: 943-978. [Crossref]

5. Levin M (2007) Large-scale biophysics: ion flows and regeneration. Trends Cell Biol17: 261-270. [Crossref]

6. Funk RH, Monsees T, Ozkucur N (2009) Electromagnetic effects - From cell biology to medicine. ProgHistochem Cytochem 43: 177-264. [Crossref]

7. Funk RH (2015) Endogenous electric fields as guiding cue for cell migration. Front Physiol6: 143. [Crossref]

8. Simanov D, Mellaart-Straver I, Sormacheva I, Berezikov E (2012) The flatworm macrostomumlignano is a powerful model organism for ion channel and stem cell research. Stem Cells Int 2012: 167265. [Crossref]

9. Binggeli R, Weinstein RC (1986) Membrane potentials and sodium channels hypotheses for growth regulation and cancer formation based on changes in sodium channels and gap junctions. J TheorBiol 123: 377-401. [Crossref]

10. Chernet BT, Levin M (2013) Transmembrane voltage potential is an essential cellular parameter for the detection and control of tumor development in a Xenopus model. Dis Model Mech 6: 595-607.

11. Funk RH (2013) Ion Gradients in Tissue and Organ Biology. BiolSyst 2: 105.

12. Freedman BD, Price MA, Deutsch CJ (1992) Evidence for voltage modulation of IL-2 production in mitogen-stimulated human peripheral blood lymphocytes. J Immunol 149: 3784-3794. [Crossref]

13. Wilson GF, Chiu SY (1993) Mitogenic factors regulate ion channels in Schwann cells cultured from newborn rat sciatic nerve. $J$ Physiol470: 501-520. [Crossref]

14. Blackiston DJ, McLaughlin KA, Levin M (2009) Bioelectric controls of cell proliferation: ion channels, membrane voltage and the cell cycle. Cell Cycle 8: $3527-$ 3536. [Crossref]

15. [Crossref]Bregestovski P1, Medina I, Goyda E (1992) Regulation of potassium conductance in the cellular membrane at early embryogenesis. J Physiol Paris 86: 109-115.

16. Sundelacruz S, Levin M, Kaplan DL (2008) Membrane potential controls adipogenic and osteogenic differentiation of mesenchymal stem cells. PLOS ONE 3: 3737. [Crossref]

17. West AE, Chen WG, Dalva MB, Dolmetsch RE, Kornhauser JM, et al. (2001) Calcium regulation of neuronal gene expression. ProcNatlAcadSci U S A98: 11024-11031. [Crossref]

18. Cervera J, Meseguer S, Mafe S (2016) The interplay between genetic and bioelectrical signaling permits a spatial regionalisation of membrane potentials in model multicellular ensembles. Sci Rep 6: 35201. [Crossref]

19. Xie W, Strong JA, Ye L, Mao JX, Zhang JM (2013) Knockdown of sodium channe NaV1.6 blocks mechanical pain and abnormal bursting activity of afferent neurons in inflamed sensory ganglia. Pain 154: 1170-1180. [Crossref] 
20. Hatch RJ, Jennings EA, Ivanusic JJ (2013) Peripheral hyperpolarization-activated cyclic nucleotide-gated channels contribute to inflammation-induced hypersensitivity of the rat temporomandibular joint. Eur J Pain 17: 972-982. [Crossref]

21. Fukumoto T, Blakely R, Levin M (2005) Serotonin transporter function is an early step in left-right patterning in chick and frog embryos. DevNeurosci27: 349-363. [Crossref]

22. Fukumoto T, Kema IP, Levin M (2005) Serotonin signaling is a very early step in patterning of the left-right axis in chick and frog embryos. CurrBiol15: 794-803. [Crossref]

23. Adams DS, Levin M (2013) Endogenous voltage gradients as mediators of cellcell communication: strategies for investigating bioelectrical signals during pattern formation.Cell Tissue Res 352:95-122. [Crossref]

24. Carneiro K, Donnet C, Rejtar T, Karger BL, Barisone GA, et al. (2011) Histone deacetylase activity is necessary for left-right patterning during vertebrate development. BMC DevBiol11:29. [Crossref]

25. Nishimura KY, Isseroff RR, Nuccitelli R (1996) Human keratinocytes migrate to the negative pole in direct current electric fields comparable to those measured in mammalian wounds. J Cell Sci109: 199-207. [Crossref]

26. McCaig CD, Zhao M (1997) Physiological electrical fields modify cell behaviour. Bioessays 19: 819-826.[Crossref]

27. Zhao M, McCaig CD, Agius-Fernandez A, Forrester JV, Araki-Sasaki K (1997) Human corneal epithelial cells reorient and migrate cathodally in a small applied electric field. Curr Eye Res 16:973-984. [Crossref]

28. Pullar CE, Baier BS, Kariya Y, Russell AJ, Horst BA, et al. (2006) beta4 integrin and epidermal growth factor coordinately regulate electric field-mediated directional migration via Rac1. MolBiol Cell 17:4925-4935. [Crossref]

29. Ozkucur N, Perike S, Sharma P, Funk RH (2011) Persistent directional cell migration requires ion transport proteins as direction sensors and membrane potential differences in order to maintain directedness. BMC Cell Biol12:4.

30. Ozkucur N, Song B, Bola S, Zhang L, Reid B, et al. (2014) NHE3 phosphorylation via PKCÎ. marks the polarity and orientation of directionally migrating cells. Cell Mol Life Sci71: 4653-4663.[Crossref]

31. Perike S, Özkucur N, Sharma P, Staroske W, Bläsche R, et al. (2014) Phospho-NHE3 forms membrane patches and interacts with beta-actin to sense and maintain constant direction during cell migration. Exp Cell Res324: 13-29. [Crossref]

32. Zhao M, Song B, Pu J, Wada T, Reid B, et al. (2006) Electrical signals control wound healing through phosphatidylinositol-3-OH kinase-gamma and PTEN. Nature 442:457460. [Crossref]

33. Nuccitelli R (2003) A role for endogenous electric fields in wound healing. Curr Top DevBiol58: 1-26.[Crossref]

34. Ojingwa JC, Isseroff RR (2003) Electrical stimulation of wound healing. $J$ Invest Dermatol121: 1-12.[Crossref]

35. Kucerova R, Walczysko P, Reid B, Ou J, Leiper LJ, et al. (2011) The role of electrical signals in murine corneal wound re-epithelialization. J Cell Physiol226: 1544-1553. [Crossref]

36. Adams DS, Masi A, Levin M (2007) $\mathrm{H}+$ pump-dependent changes in membrane voltage are an early mechanism necessary and sufficient to induce Xenopus tail regeneration. Development 134:1323-1335. [Crossref]

37. Ozkucur N, Epperlein HH, Funk RH (2010) Ion imaging during axolotl tail regeneration in vivo. DevDyn239: 2048-2057.[Crossref]

38. Tseng AS, Beane WS, Lemire JM, Masi A, Levin M (2010) Induction of vertebrate regeneration by a transient sodium current. J Neurosci30: 13192-13200.[Crossref]

39. Antonsson EK, Mann RW (1985) The frequency content of gait. $J$ Biomech18: 39-47. [Crossref]

40. Becker RO (1985) The body electric: electromagnetism and the foundation of life William Morrow and Company, New York.

41. Hastings GW, Mahmud FA (1988) Electrical effects in bone. J Biomed Eng10: 515 521.[Crossref]

42. Otter MW, McLeod KJ, Rubin CT (1998) Effects of electromagnetic fields in experimental fracture repair. ClinOrthopRelatRes : S90-104.[Crossref]

43. Bertram R, Sherman A, Satin LS (2007) Metabolic and electrical oscillations: partners in controlling pulsatile insulin secretion. Am J PhysiolEndocrinolMetab 293:E890900. [Crossref]
44. Milo R, Phillips R (2015) Cell biology by the numbers. Garland Science, USA. http:// book.bionumbers.org/how-many-reactions-do-enzymes-carry-out-each-second/

45. McLeod KJ, Rubin CT, Donahue HJ (1995) Electromagnetic fields in bone repair and adaption. Radio Sci 30:233-244.

46. Fitzsimmons RJ, Strong DD, Mohan S, Baylink DJ (1992) Low-amplitude, lowfrequency electric field stimulated bone cell proliferation may in part be mediated by increased IGF-II release. J Cell Physiol 150:84-89.[Crossref]

47. Fitzsimmons RJ, Baylink DJ (1994) Growth factors and electromagnetic fields in bone. ClinPlastSurg21: 401-406.[Crossref]

48. Cho MR, Thatte HS, Lee RC, Golan DE (1996) Reorganization of microfilament structure induced by ac electric fields. Faseb $J$ 10:1552-1558. [Crossref]

49. Tsong TY(1992) Molecular recognition and processing of periodic signals in cells: study of activation of membrane ATPases by alternating electric fields. BiochimBiophysActa1113: 53-70.[Crossref]

50. Cifra M, Fields JZ, Farhadi A (2011) Electromagnetic cellular interactions. ProgBiophysMolBiol105: 223-246.[Crossref]

51. Kruglikov IL, Dertinger H (1994) Stochastic resonance as a possible mechanism of amplification of weak electric signals in living cells. Bioelectromagnetics 15:539-547. [Crossref]

52. Lin H, Blank M, Goodman R (1999) A magnetic field-responsive domain in the human HSP70 promoter. J Cell Biochem 75: 170-176.[Crossref]

53. Lin H, Blank M, Rossol-Haseroth K, Goodman R (2001) Regulating genes with electromagnetic response elements. J Cell Biochem 81:143-148. [Crossref]

54. Blank (2012) www.bioinitiative.org/.../sec07_2012_Evidence_for_Stress_Resp

55. Pereda AE (2014) Electrical synapses and their functional interactions with chemical synapses. Nat Rev Neurosci15: 250-263.[Crossref]

56. Simkó M (2007) Cell type specific redox status is responsible for diverse electromagnetic field effects. Curr Med Chem14: 1141-1152.[Crossref]

57. Wang X, Bukoreshtliev NV, Gerdes HH (2012) Developing neurons form transien nanotubes facilitating electrical coupling and calcium signaling with distant astrocytes. PLoS One 7:e47429. [Crossref]

58. Rosenspire AJ, Kindzelskii AL, Simon BJ, Petty HR (2005) Real-time control of neutrophil metabolism by very weak ultra-low frequency pulsed magnetic fields. Biophys J88:3334-3347. [Crossref]

59. Funk RH, Knels L, Augstein A, Marquetant R, Dertinger HF (2014)Potent stimulation of blood flow in fingers of volunteers after local short-term treatment with lowfrequency magnetic fields from a novel device. Evid Based Complement Alternat Med 2014:543-564.

60. Graubner N, Wehner H, Mikus E (2007) PAVK und die unterschaetzteMoeglichkeit der EinflussnahmedurchphysikalischeTherapieoptionen. Die Naturheilkunde 4:49-50.

61. Grohmann G, Krauß M, Poehlmann G, Baer H, Figulla HR (2000) ZurMakro- und Microzirkulation am Vorfußunterverschiedenen Kompressionsdrueckenbeigesunden Probanden. Phlebologie 29:114-123

62. Wiltschko R, Wiltschko W (2014) Sensing magnetic directions in birds: radical pair processes involving cryptochrome. Biosensors (Basel) 4:221-242. [Crossref]

63. Weintraub MI, Herrmann DN, Smith AG, Backonja MM, Cole SP (2009) Pulsed electromagnetic fields to reduce diabetic neuropathic pain and stimulate neuronal repair: a randomized controlled trial. Arch Phys Med Rehabil 90:1102-1109. [Crossref]

64. Wuschech H, von Hehn U, Mikus E, Funk RH (2015) Effects of PEMF on patients with osteoarthritis: Results of a prospective, placebo-controlled, double-blind study. Bioelectromagnetics 36:576-585. [Crossref]

65. Shah JP, Midkiff P, Brandt PC, Sisken BF (2001) Growth and differentiation of PC6 cells: the effects of pulsed electromagnetic fields (PEMF). Bioelectromagnetics22: 267271.[Crossref]

66. Graves MS, Hassell T, Beier BL, Albors GO, Irazoqui PP (2011) Electrically mediated neuronal guidance with applied alternating current electric fields. Ann Biomed Eng 39:1759-1767. [Crossref]

67. Kudo TA, Kanetaka H, Shimizu Y, Abe T, Mori H, et al. (2013) Induction of neuritogenesis in PC12 cells by a pulsed electromagnetic field via MEK-ERK1/2 signaling. Cell StructFunct38: 15-20.[Crossref] 
68. Lei T, Jing D, Xie K, Jiang M, Li F, et al. (2013) Therapeutic effects of 15 Hz pulsed electromagnetic field on diabetic peripheral neuropathy in streptozotocin-treated rats. PLoS One 8:e61414. [Crossref]

69. Li Y, Yan X, Liu J, Li L, Hu X, et al. (2014) Pulsed electromagnetic field enhances brain-derived neurotrophic factor expression through L-type voltage-gated calcium channel- and Erk-dependent signaling pathways in neonatal rat dorsal root ganglion neurons. NeurochemInt75:96-104. [Crossref]

70. Mohammadi R, Faraji D, Alemi H, Mokarizadeh A (2014) Pulsed electromagnetic fieldaccelerate functional recovery of transected sciatic nerve bridged by chitosaconduit: an animal model study. Int J Surg 12:1278-1285.

71. Seong Y, Moon J, Kim J (2014) Egrl mediated the neuronal differentiation induced by extremely low-frequency electromagnetic fields. Life Sci102:16-27. [Crossref]

72. Kim YT, Hei WH, Kim S, Seo YK, Kim SM, et al. (2015) Co-treatment effect of pulsed electromagnetic field (PEMF) with human dental pulp stromal cells and FK506 on the regeneration of crush injured rat sciatic nerve. Int J Neurosci125:774-783. [Crossref]

73. Schatz A, Rock T, Naycheva L, Willmann G, Wilhelm B, et al. (2011) Transcorneal electrical stimulation for patients with retinitis pigmentosa: a prospective, randomized, sham-controlled exploratory study. Invest Ophthalmol Vis Sci 52: 4485-4496. [Crossref]

74. Nishida N, Yamagishi S, Mizukami H, Yagihashi S (2013) Impaired nerve fiber regeneration in axotomized peripheral nerves in streptozotocin-diabetic rats. J Diabetes Investig 4:533-539. [Crossref]

75. Jin HY, Baek HS, Park TS (2015) Morphologic Changes in Autonomic Nerves in Diabetic Autonomic Neuropathy. Diabetes Metab J 39:461-467. [Crossref]

76. Shimatani Y, Nodera H, Osaki Y, Banzrai C, Takayasu K, et al. (2015) Upregulation of axonal HCN current by methylglyoxal: Potential association with diabetic polyneuropathy. ClinNeurophysiol 126:2226-2232. [Crossref]

77. Ferroni L, Tocco I, De Pieri A, Menarin M, Fermi E, et al.(2016) Pulsed magnetic therapy increases osteogenic differentiation of mesenchymal stem cells only if they are pre-committed. Life Sci152:44-51. [Crossref]

78. Zhai M, Jing D, Tong S, Wu Y, Wang P, et al. (2016) Pulsed electromagnetic fields promote in vitro osteoblastogenesis through a Wnt/ß-catenin signaling-associated mechanism. Bioelectromagnetics[Crossref]

79. Tucker JJ, Cirone JM, Morris TR, Nuss CA, Huegel J, et al. (2016) Pulsed electromagnetic field therapy improves tendon-to-bone healing in a rat rotator cuff repair model. J Orthop Res[Crossref]

80. Urnukhsaikhan E, Cho H, Mishig-Ochir T, Seo YK, Park JK (2016) Pulsed electromagnetic fields promote survival and neuronal differentiation of human BMMSCs. Life Sci151: 130-138.[Crossref]

81. Hei WH, Kim S, Park JC, Seo YK, Kim SM, et al. (2016) Schwann-like cells differentiated from human dental pulp stem cells combined with a pulsed electromagnetic field can improve peripheral nerve regeneration. Bioelectromagnetics[Crossref]

82. Veronesi F, Torricelli P, Giavaresi G, Sartori M, Cavani F, et al. (2014) In vivo effect of two different pulsed electromagnetic field frequencies on osteoarthritis. J Orthop Res 32:677-685. [Crossref]

83. Benazzo F, Cadossi M, Cavani F, Fini M, Giavaresi G, et al. (2008) Cartilage repair with osteochondralautografts in sheep: effect of biophysical stimulation with pulsed electromagnetic fields. J Orthop Res26:631-642. [Crossref]
84. Ciombor DM, Aaron RK, Wang S, Simon B (2003) Modification of osteoarthritis by pulsed electromagnetic field--a morphological study. Osteoarthritis Cartilage 11:455462. [Crossref]

85. De Mattei M, Caruso A, Pezzetti F, Pellati A, Stabellini G, et al. (2001) Effects of pulsed electromagnetic fields on human articular chondrocyte proliferation. Connect Tissue Res 42:269-279. [Crossref]

86. De Mattei M, Fini M, Setti S, Ongaro A, Gemmati D, et al. (2007) Proteoglycan synthesis in bovine articular cartilage explants exposed to different low-frequency lowenergy pulsed electromagnetic fields. Osteoarthritis Cartilage 15:163-168. [Crossref]

87. De Mattei M, Pasello M, Pellati A, Stabellini G, Massari L, et al. (2003) Effects of electromagnetic fields on proteoglycan metabolism of bovine articular cartilage explants. Connect Tissue Res 44:154-159. [Crossref]

88. Fini M, Giavaresi G, Torricelli P, Cavani F, Setti S, et al. (2005) Pulsed electromagnetic fields reduce knee osteoarthritic lesion progression in the aged Dunkin Hartley guinea pig. J Orthop Res23:899-908. [Crossref]

89. Fini M, Torricelli P, Giavaresi G, Aldini NN, Cavani F, et al.(2008) Effect of pulsed electromagnetic field stimulation on knee cartilage, subchondral and epyphiseal trabecular bone of aged Dunkin Hartley guinea pigs. Biomed Pharmacother 62:709715.[Crossref]

90. Nicolin V, Ponti C, Baldini G, Gibellini D, Bortul R, et al. (2007) In vitro exposure of human chondrocytes to pulsed electromagnetic fields. Eur J Histochem51: 203-212. [Crossref]

91. Ongaro A, Pellati A, Masieri FF, Caruso A, Setti S, et al.(2011)Chondroprotective effects of pulsed electromagnetic fields on human cartilage explants. Bioelectromagnetics 32:543-551. [Crossref]

92. Boopalan PR, Arumugam S, Livingston A, Mohanty M, Chittaranjan S (2011) Pulsed electromagnetic field therapy results in healing of full thickness articular cartilage defect. IntOrthop 35:143-148. [Crossref]

93. Aaron RK, Ciombor DM (2004) Pain in osteoarthritis. Med Health R I 87: 205-209. [Crossref]

94. Boopalan PR, Daniel AJ, Chittaranjan SB (2009) Managing skin necrosis and prosthesis subluxation after total knee arthroplasty. J Arthroplasty24: 322.[Crossref]

95. Ciombor DM, Lester G, Aaron RK, Neame P, Caterson B (2002) Low frequency EMF regulates chondrocyte differentiation and expression of matrix proteins. $J$ Orthop Res20:40-50. [Crossref]

96. Iannitti T, Fistetto G, Esposito A, Rottigni V, Palmieri B (2013) Pulsed electromagnetic field therapy for management of osteoarthritis-related pain, stiffness and physical function: clinical experience in the elderly. ClinInterv Aging 8:1289-1293. [Crossref]

97. Negm A, Lorbergs A, Macintyre NJ (2013) Efficacy of low frequency pulsed subsensory threshold electrical stimulation vs placebo on pain and physical function in people with knee osteoarthritis: systematic review with meta-analysis. Osteoarthritis Cartilage 21:1281-1289. [Crossref]

98. Ryang We S, Koog YH, Jeong KI, Wi H (2013) Effects of pulsed electromagnetic field on knee osteoarthritis: a systematic review. Rheumatology (Oxford) 52:815-824. [Crossref]

Copyright: (C2017 Funk RHW. This is an open-access article distributed under the terms of the Creative Commons Attribution License, which permits unrestricted use, distribution, and reproduction in any medium, provided the original author and source are credited. 